\title{
Geothermal-Sludge-Based Sodium Silicate Catalyst Deactivation in Methyl Ester Production Process
}

\author{
Inasanti Pandan Wangi ${ }^{1)}$, Indra Perdana ${ }^{1)^{*}}$ \\ 1) Chemical Engineering Department, Faculty of Engineering, Universitas Gadjah Mada \\ ${ }^{*}$ Correspondence Email: iperdana@ugm.ac.id
}

\begin{abstract}
The deactivation of solid catalyst is one of the catalyst parameters to predict the reuse of catalyst. In this research, sodium silicate was used to catalyze the transesterification of corn oil with methanol. Sodium silicate was produced by reacting silica with $\mathrm{NaOH}$. Silica was extracted by gelation method from Dieng Geothermal Power Plant solid sludge which had 55\% (w/w) of silica content. Sodium silicate catalyst was activated by calcination process at $400^{\circ} \mathrm{C}$, heating rate of $20^{\circ} \mathrm{C} / \mathrm{min}$, and holding time $3 \mathrm{~h}$. The transesterification was performed by adding $5 \%(\mathrm{w} / \mathrm{w})$ catalyst to a mixture of methanol and corn oil (mole ratio of 9:1) and further incubated at $60^{\circ} \mathrm{C}$ for $60 \mathrm{~min}$. The sample was taken at $0,5,10,20,40$ and 60 minutes. The catalyst was separated, washed with methanol and further heated at $120^{\circ} \mathrm{C}$ for $2 \mathrm{~h}$. The catalyst was then used for about 4 times. This research showed that the activity of catalyst decreased after it was reused for several batches of reactions. The most fitting reaction kinetics was modelled with second-order kinetics. The highest conversion obtained using fresh catalyst was $91,67 \%$.
\end{abstract}

Keywords: geothermal waste, solid catalyst, sodium silicate, transesterification, deactivation

\section{INTRODUCTION}

In producing methyl ester, catalyst was needed to increase the conversion of the product. Normally, the process used homogeneous alkali catalyst, however there are several difficulties in the separation process. Therefore, heterogeneous catalyst was developed as an alternative. Several catalysts used for transesterification reaction were $\mathrm{CaO}$ (Liu et al., 2008 dan Wang et al., 2013), $\mathrm{Ca}\left(\mathrm{OCH}_{3}\right)_{2}$ (Liu et al., 2008), $\mathrm{Na}_{2} \mathrm{SiO}_{3}$ (Guo et al., 2010 and Long et al., 2011).

Sodium silicate $\left(\mathrm{Na}_{2} \mathrm{SiO}_{3}\right)$ is a suitable heterogeneous alkali catalyst for transesterification reaction because it could prevent saponification and is easy to separate from the product and reactant (Guo et al., 2010). In this research, the sodium silicate catalyst was obtained from the reaction of Sodium hydroxide $(\mathrm{NaOH})$ with silica $\left(\mathrm{SiO}_{2}\right)$. The silica was extracted from the solid waste of PT. Geodipa Energi Dieng geothermal sludge. From the analysis in the previous experiment, it was found that the solid waste contained $55 \%$ of amorphous silica (Riyanto et al., 2010).

One of the problems in using a heterogeneous catalyst is catalyst deactivation, which is the decrease of catalyst activity during the reaction (Forzatti and Lietti, 1999). Deactivation can be caused by sintering or aging from catalyst reformation, coking or fouling from coke formation on the catalyst surface, and poisoning from irreversible chemosorption of catalyst poison (Fogler, 2005). Therefore, catalyst deactivation is an important parameter for measuring the ability of heterogeneous catalyst.

This research was focused on studying sodium silicate catalyst deactivation in transesterification reaction of corn oil and methanol to produce methyl ester. This research aimed to study the kinetics of the rate of deactivation of sodium silicate catalyst. The study of sodium silicate deactivation was previously done by Guo et al. (2010) using standard sodium silicate and Dermawan (2013) using sodium silicate extracted from silica gel.

\section{MATERIALS AND METHODS \\ Materials}

The raw materials used in this experiment were geothermal sludge obtained from Dieng's Geothermal Power Plant, in which silica content was 55\% (w/w) (Riyanto et al., 2010), Tropicana corn oil, sodium hydroxide with $99.9 \%$ purity, methanol with $98 \%$ purity were obtained from Merck.

\section{Sodium Silicate Catalyst Production from Geothermal Sludge}

The silica extraction from geothermal sludge was done according to Reningtyas et al. (2012). About $1600 \mathrm{~mL}$ of geothermal sludge was initially washed with distilled water with the sludge and distilled water (sludge and distilled water ratio of 1:2.) The geothermal sludge was then filtered and dried in an oven at $150^{\circ} \mathrm{C}$ for $16 \mathrm{~h}$. The remaining dried material was then pulverized and sieved using 60 mesh sieve.

About $20 \mathrm{~g}$ of dry sludge was extracted using $800 \mathrm{~mL}$ $\mathrm{NaOH} 1.5 \mathrm{~N}$ solution at $90^{\circ} \mathrm{C}$ for $120 \mathrm{~min}$ and then filtered by vacuum filter to obtain the silica. About $50 \mathrm{~mL}$ of filtrate was then reacted with $\mathrm{HCl} 2 \mathrm{~N}$ drop by drop while being stirred by magnetic stirrer until forming a gel-phase. The gel was incubated for $18 \mathrm{~h}$ and dried in the oven at $150^{\circ} \mathrm{C}$ for $6 \mathrm{~h}$. The dried gel was then washed with distilled water $(1 / 50 \mathrm{~g} / \mathrm{mL}$ ratio of dried gel to distilled water) for $10 \mathrm{~min}$ for every washing cycle. The washing process was repeated until the $\mathrm{pH}$ of the washing liquid closed to neutral. The gel was then dried in the oven at $120^{\circ} \mathrm{C}$ for $4 \mathrm{~h}$ to obtain the clean and dry gel called xerogel.

The $\mathrm{NaOH}$ solution was made by diluting $8.7 \mathrm{~g}$ of $\mathrm{NaOH}$ pellets in $8.7 \mathrm{~mL}$ of distilled water. About $7.5 \mathrm{~g}$ of xerogel was added to the $\mathrm{NaOH}$ solution gradually while being 
stirred using magnetic stirrer at $60^{\circ} \mathrm{C}$ until homogeneous. The solution was then dried in the oven at $120^{\circ} \mathrm{C}$ for $5-6$ $\mathrm{h}$, and then calcined at $400^{\circ} \mathrm{C}$ for $3 \mathrm{~h}$ with a heating rate of $20^{\circ} \mathrm{C} / \mathrm{min}$ to obtain the sodium silicate catalyst.

\section{Transesterification Reaction}

The transesterification reaction procedure was done according to Chendrika (2013). About $200 \mathrm{~g}$ of corn oil was heated until $60^{\circ} \mathrm{C}$ and kept at a constant temperature. About $260 \mathrm{~mL}$ of methanol and $10 \mathrm{~g}$ of sodium silicate catalyst were mixed and heated in a flask equipped with thermometer, stirrer and condenser until it reaches $60^{\circ} \mathrm{C}$ and then stirred for an hour to activate the catalyst. After an hour, the heated corn oil was added to the mixture. The transesterification reaction was performed at $60^{\circ} \mathrm{C}, 410$ rpm stirring speed, for $60 \mathrm{~min}$. Samples of about $5 \mathrm{~mL}$ were taken at 5, 10, 20, 40 and 60 min since the corn oil was added to the mixture. Samples were then centrifuged at 200 rpm for 5-10 min. About $1 \mathrm{~g}$ of natant phase solution was obtained and analysed by iodometric analysis.

\section{Kinetic Reaction}

The rate of transesterification reaction can be modelled by first, second and third-order reaction kinetics. The reaction used in this research was:

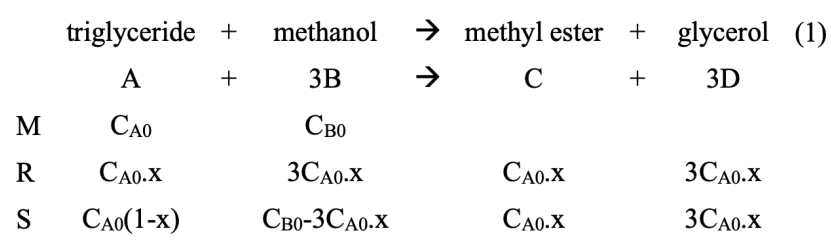

The reaction was run in a batch condition so that the accumulation can be determined from only the rate of reaction. The rate of reaction for each order was:

$$
\begin{aligned}
& 1^{\text {st }} \text { order: }-r_{A}=k_{1} \cdot C_{A} \\
& 2^{\text {nd }} \text { order: }-r_{A}=k_{2} \cdot C_{A}^{2} \\
& 3^{\text {rd }} \text { order: }-r_{A}=k_{3} \cdot C_{A}^{3}
\end{aligned}
$$

Each order was derived by time and conversion. Equations which showed the relationship between conversion ( $\mathrm{x}$ ) and time (t) for each order could then be obtained as follows:

$$
\begin{aligned}
& 1^{\text {st }} \text { order: }-\ln (1-x)=k_{1} \cdot t \\
& 2^{\text {nd }} \text { order: } \frac{x}{1-x}=k_{2} \cdot C_{A 0} \cdot t \\
& 3^{\text {rd }} \text { order: } \frac{1}{2(1-x)^{2}}-\frac{1}{2}=k_{3} \cdot C_{A 0} \cdot t
\end{aligned}
$$

Equation (5), (6) and (7) was then linearized as $\mathrm{p}=\mathrm{Aq}+\mathrm{B}$ equation form, therefore the linearization of each order is as follows:

Basic equation: $p=A q+B$

with,

$$
\begin{aligned}
1 \text { st order } \quad p & =-\ln (1-x) \\
q & =t \\
A & =k_{1} \\
B & =\text { constant }
\end{aligned}
$$

$$
\begin{aligned}
2^{\text {nd }} \text { order: } & p=\frac{x}{1-x} \\
q & =t \\
A & =k_{2} \cdot C_{A 0} \\
B & =\text { constant } \\
3^{\text {rd }} \text { order: } \quad p & =\frac{1}{2(1-x)^{2}}-\frac{1}{2} \\
q & =t \\
A & =k_{3} \cdot C_{A 0} \\
B & =\text { constant }
\end{aligned}
$$

Each order was plotted, then the most suitable equation was determined by comparing the $\mathrm{R}^{2}$ value, and we were able to obtain the most suitable reaction kinetics for transesterification reaction.

\section{Catalyst Recycling Process}

The catalyst and the product of reaction were separated. The catalyst was washed with methanol and was heated in the oven at $120^{\circ} \mathrm{C}$ for two hours. Then, the catalyst was weighed and was reused for the next cycle of transesterification reaction with the ratio of methanol and corn oil 9:1 (n/n) and the mass of catalyst 5\% (w/w) of corn oil for every cycle. The catalyst used in each cycle was analysed using FTIR Spectroscopy.

\section{Iodometric Analysis}

The natant phase was mixed $50 \mathrm{~mL}$ of Chloroform and 12.5 $\mathrm{mL}$ of acetic acid and then shaken for $1 \mathrm{~min}$. After shaking, the solution was mixed with distilled water until it reached $500 \mathrm{~mL}$ of volume. The mixture was then shaken and was incubated overnight until it formed two immiscible layers of liquids. About $50 \mathrm{ml}$ of the upper layer, called the aqueous layer, was added to the Erlenmeyer flask and was mixed with about $2 \mathrm{~mL}$ of Periodic acid and then was incubated for $30 \mathrm{~min}$. After $30 \mathrm{~min}, 2 \mathrm{~mL}$ of Potassium iodide (KI) was added, and the solution was incubated in a dark place for one min. After one min, the mixture was then titrated using $\mathrm{Na}_{2} \mathrm{~S}_{2} \mathrm{O}_{3}$ solution with starch indicator until it formed a clear solution.

The total and free glycerol was calculated by the following equation:

$$
G=\frac{2,302(B-C) \cdot N_{N a_{2} S_{2} O_{3}}}{W}
$$

$\mathrm{G}=$ total glycerol or free glycerol, \% weight

$\mathrm{B}=$ volume of $\mathrm{Na}_{2} \mathrm{~S}_{2} \mathrm{O}_{3}$ used for blanc titration, $\mathrm{mL}$

$\mathrm{C}=$ volume of $\mathrm{Na}_{2} \mathrm{~S}_{2} \mathrm{O}_{3}$ used for sample titration, $\mathrm{mL}$

$$
\begin{aligned}
& \mathrm{N}_{\mathrm{Na}_{2} \mathrm{~S}_{2} \mathrm{O}_{3}}=\text { normality of } \mathrm{Na}_{2} \mathrm{~S}_{2} \mathrm{O}_{3}, \mathrm{~mol} / \mathrm{L} \\
& \mathrm{W}=\frac{A \times P}{450}
\end{aligned}
$$


$\mathrm{P}=$ volume of aquatic layer $(50 \mathrm{~mL})$

The conversion of the reaction was calculated by the following equation:

$$
\frac{G b b s}{G t t l} \times 100 \%
$$

$\mathrm{X}=$ conversion, $\%(\mathrm{w} / \mathrm{w})$

\section{Fourier Transform Infra-Red (FTIR) Spectroscopy Analysis}

FTIR Spectroscopy (8201 PC, Shimadzu Co., Japan FTIR Spectroscopy) was used to analyse the functional groups of the catalyst, especially the siloxane.

\section{RESULT AND DISCUSSION \\ Transesterification Mechanism Catalysed by Sodium Silicate Catalyst}

This experiment studied the transesterification reaction kinetics before the catalyst deactivation (initial state) and the reaction kinetics of sodium silicate catalyst in 4 reaction cycle. The rate of deactivation calculation was done by following the previous works. The separated catalyst was dried in the oven to reduce the water content. Before dried, the catalyst was washed by methanol to remove the oil attached in the catalyst. The deactivation type in this process is poisoning by corn oil (Bartholomew, 2001; Dermawan, 2013; Fogler, 2005; Forzatti and Lietti, 1999).

The conversion of corn oil in every cycle of transesterification is shown in Figure 1.

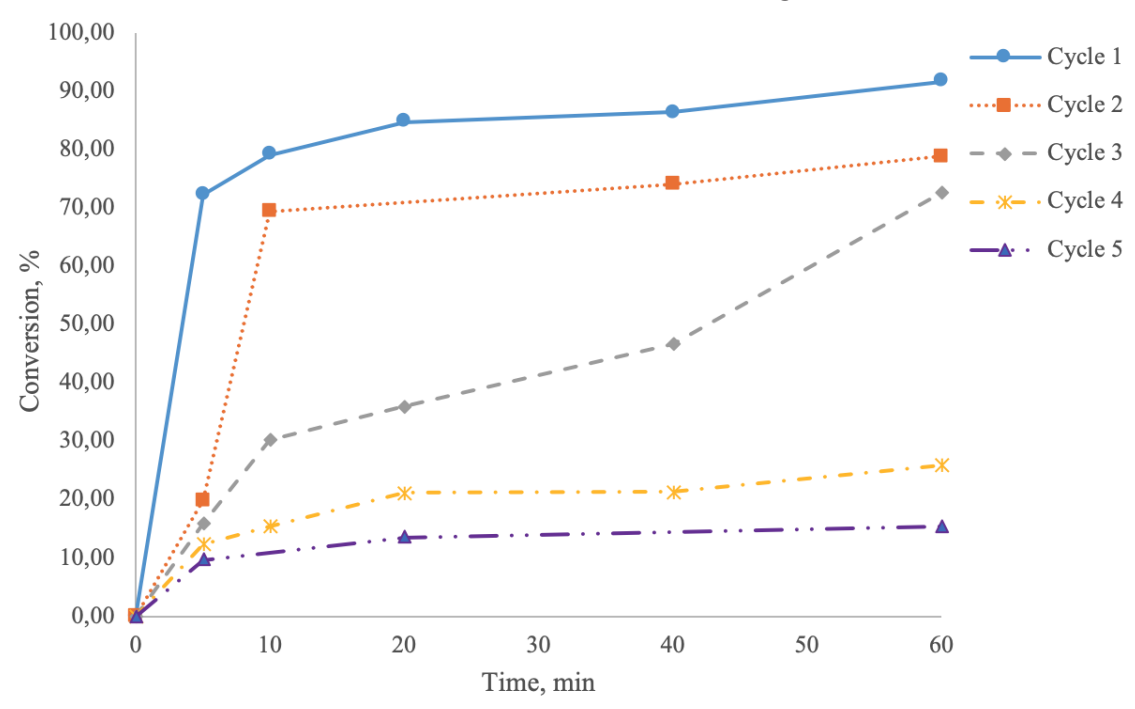

Figure 1. Conversion of Corn Oil in Every Cycle $\left(60^{\circ} \mathrm{C}, 410 \mathrm{rpm}, 60 \mathrm{~min}\right)$

In the first cycle, the catalyst was fresh. From Figure 1, it can be seen that the conversion of corn oil increased by time. This result is in accordance with the reaction kinetics theory in which the conversion of corn oil into methyl ester increased with time. The conversion obtained in the first cycle after 60 min was $91.67 \%$.

The catalyst was reused for the second to the fifth cycle. From Figure 1, it could be seen that the conversion at the same time of reaction decreased with the increasing
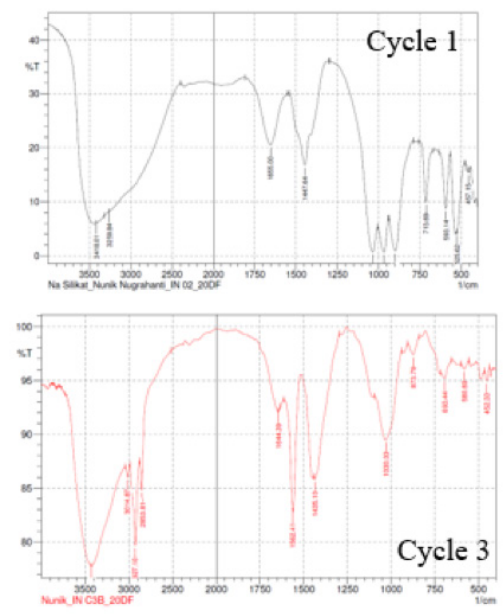

frequency of catalyst reused from the first to the fifth cycle. This phenomenon occurred because of catalyst activity degradation, which is called deactivation (Bartholomew, 2001; Dermawan, 2013; Fogler, 2005; Forzatti and Lietti, 1999).

\section{FTIR Spectra of Sodium Silicate Catalyst}

The FTIR analysis result of sodium silicate catalyst in every cycle is shown in Figure 2.
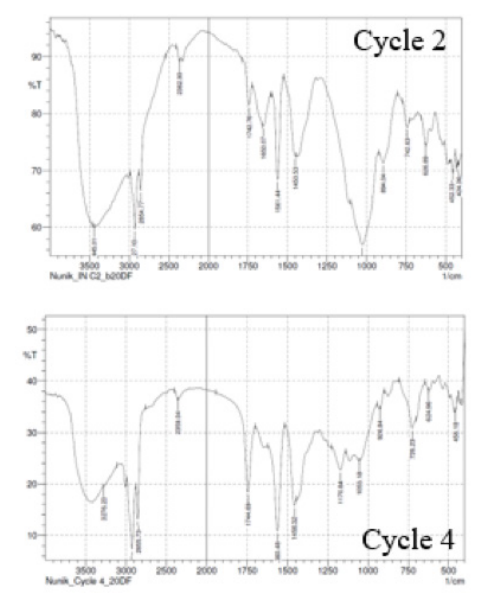

Figure 2. FTIR Spectra of Sodium Silicate Catalyst in Every Cycle 
In Figure 2, it showed that the intensity at wavenumber around $1000 \mathrm{~cm}^{-1}$ and $960 \mathrm{~cm}^{-1}$ corresponds to stretching and bending vibrations of Si-O-Na (Guo et al., 2010). In the first cycle, it showed that the peak is narrow and sharp at wavenumber around $1000 \mathrm{~cm}^{-1}$. It shows that the Si-O-Na group in a catalyst was relatively homogeneous. Therefore, its ability to catalyze was excellent, as proofed by the conversion at the first cycle that showed the highest result $(91.67 \%)$.

In the second and third cycle, it showed that the peak was broader but sharp at wavenumber around 1000 $\mathrm{cm}^{-1}$. It showed that the $\mathrm{Si}-\mathrm{O}-\mathrm{Na}$ group distributed more heterogeneously compared to the first cycle. This distribution was caused by the loss or damage in the SiO-Na group. On the other hand, there was a peak formed at wavelength $2900 \mathrm{~cm}^{-1}$ which detected the existence of C-H group. This group is suspected from the oil that still attached to the catalyst which caused the catalyst activity degradation, as proofed by the reaction conversion decrease.

In the fourth cycle, it is showed that the peak was small and uneven at wavenumber around $1000 \mathrm{~cm}^{-1}$. It showed that the Si-O-Na group distributed even more heterogeneously compared to the previous cycle. This heterogeneous distribution was caused by more loss or damage to the Si-O-Na group. Besides, the peak is narrower and deeper at wavenumber $2900 \mathrm{~cm}^{-1}$ compared to the second and third cycle. It showed that the contaminant attached to the catalyst much higher than in the second and third cycle. In result, the catalyst active-site was covered more, and the reaction conversion decreased more. The catalyst for the fifth cycle could not be analyzed by FTIR because the contaminant attached to the catalyst was too much and was difficult to remove. Therefore, the reaction conversion decreased mostly in the fifth cycle.

\section{Reaction Kinetics Determination}

The linearization method was used to determine the best approach to the reaction kinetics. The data used was conversion versus time of the first cycle. The data was modelled to 3 types of reaction order kinetics equation using equation (5), (6) and (7) that was linearized using equation (8). The linearization result is shown in Figure 3.

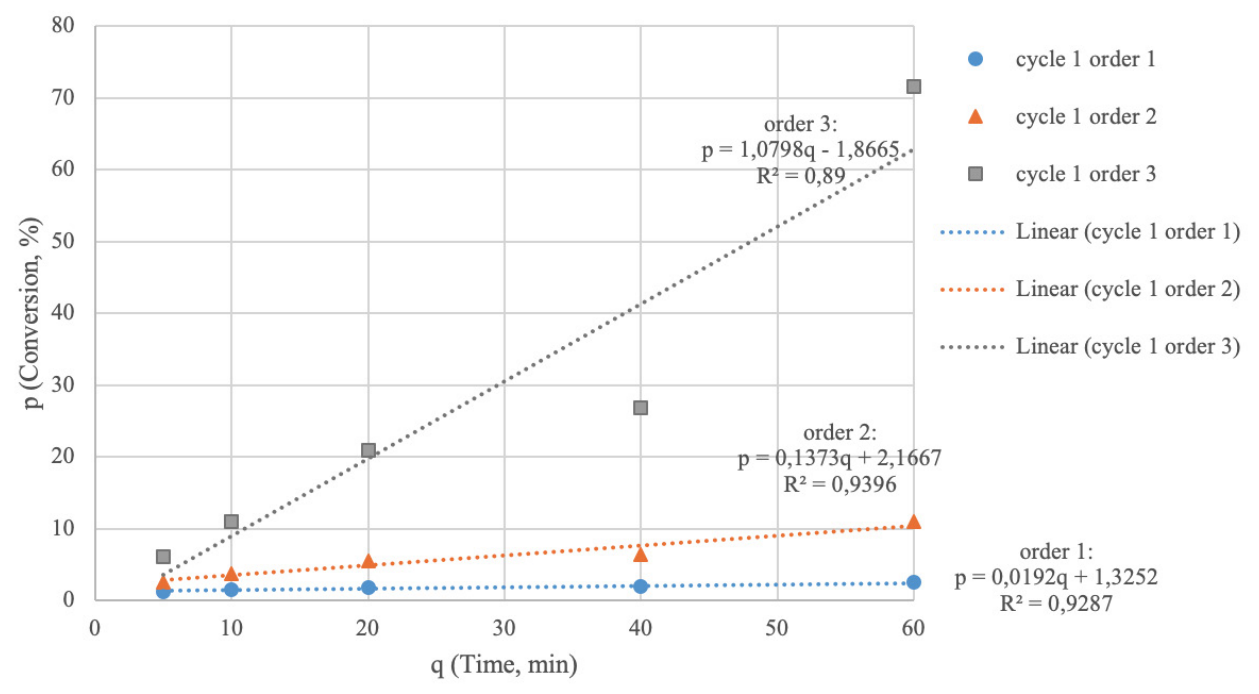

Figure 3. Reaction Kinetics Linearization

From Figure 3, it can be seen that linearization for the second-order has the $\mathrm{R}^{2}$ value nearest to 1 compared to the first and third order, which indicated that the second-order has the better accuracy than the other model. Thus, it can be concluded that catalyst deactivation follows second order kinetics. However, there is no equation that has $\mathrm{R}^{2}$ value close to 1. According to Dermawan (2013) and Richard et al. (2011), for the transesterification of vegetable oil and alcohol, pseudo-second-order reaction gives a more suitable model compared to the pseudo-first-order reaction. Transesterification reaction in biodiesel production using a batch reactor can be considered as a pseudo-homogeneous reaction with no mass transfer limitations (Marjanovic et al., 2010). Therefore, the reaction in this research can be modelled using second-order reaction kinetics.

\section{Rate of Reaction Constant}

The rate of reaction constant can be determined by using second-order reaction kinetics. The rate of reaction constant calculation for every cycle is shown in Table 1.

Table 1. Rate of Reaction Constant Calculation in Every Cycle

\begin{tabular}{cc}
\hline Cycle & $\begin{array}{c}\text { Reaction rate constant } \\
\text { (k), L/(mole.min) }\end{array}$ \\
\hline 1 & 0.0980 \\
2 & 0.0354 \\
3 & 0.0286 \\
4 & 0.0024 \\
5 & 0.0009 \\
\hline
\end{tabular}

In Table 1, it showed that the more catalyst was reused, the more the rate of reaction constant decreased. This was caused by catalyst deactivation. The occurred deactivation in this research was caused by corn oil (reactant) that attached to the catalyst (Bartholomew, 2001; Dermawan, 2013; Fogler, 2005; Forzatti and Lietti, 1999). Coking and sintering did not occur in this research because it only 
happens in a high-temperature reaction (Bartholomew, 2001; Dermawan, 2013; Fogler, 2005; Forzatti and Lietti, 1999).

Before reuse, the catalyst needs to be reactivated. The reactivation aims to remove the impurities attached to the catalyst so that the active site of the catalyst can be reused to catalyze (Argyle and Bartholomew, 2015; Guo et al., 2010; Long et al., 2011). In this research, the deactivation type was poisoning with the corn oil as the catalyst poison. The oil removal cannot be done by heating, because the oil will coagulate in the catalyst and will be difficult to separate at high temperature. Therefore, the oil removal was done by washing with methanol because oil dissolves in methanol, but sodium silicate catalyst did not. In this research, the washing process occurred at ambient temperature. However, the catalyst reactivation was not very successful, as proofed by the conversion of the methyl ester using reused catalyst decrease significantly. Therefore, research about catalyst reactivation method is essential to be developed.

\section{CONCLUSION}

With the increasing number of cycle, the activity of catalyst decreased because of the contaminant attached to the catalyst. Therefore, the conversion at the same time of reaction decreased. The reaction in this research can be modelled by second-order reaction kinetics. The highest conversion was obtained by reacting corn oil and methanol using sodium silicate catalyst from geothermal sludge for an hour reaction was $91.67 \%$. Further studies about catalyst reactivation are needed to develop the impurities removal method for the contaminant attached to the catalyst.

\section{REFERENCES}

Argyle, M. D. and Bartholomew, C. H. 2015. Heterogeneous Catalyst Deactivation and Regeneration: A Review. Catalysts. 5:145-269.

Bartholomew, C. H. 2001. Mechanisms of Catalyst Deactivation. Applied Catalysis A: General. 212:17-60.

Chendrika, L. 2013. Pengaruh Suhu dan laju Kenaikan Suhu Kalsinasi Terhadap Karakteristik Natrium Silikat sebagai Katalisator Basa Padat. Thesis Program Studi Teknik Kimia. Magister Teknik Proses. Universitas Gadjah Mada. Yogyakarta.
Dermawan, M. R. 2013. Deaktivasi Katalis Natrium Silikat untuk Reaksi Transesterifikasi Pembentukan Biodiesel. Laporan Penelitian Program Studi Teknik Kimia. Departemen Teknik Kimia, Universitas Gadjah Mada. Yogyakarta.

Fogler, H. S. 2005. Elements of Chemical Reaction Engineering. $4^{\text {th }}$ ed., pp. 707-716, Prentice Hall Professional Technical Reference, Massachusetts.

Forzatti, P. and Lietti, L. 1999. Catalyst Deactivation. Catalysis Today. 52:165-181.

Guo, F., Peng, Z. G., Dai, J.Y., and Xiu, Z. L. 2010. Calcined Sodium Silicate as Solid Base Catalyst for Biodiesel Production. Fuel Processing Technology. 91:322-328.

Liu, X., He, H., Wang, Y., Zhu, S., Piao, X. 2008. Transesterification of Soybean Oil to Biodiesel Using $\mathrm{CaO}$ as A Solid Base Catalyst. Fuel. 87:216-221.

Liu, X., Piao, X., Wang, Y., Zhu, S., and He, H. 2008. Calcium Methoxide as A Solid Base Catalyst for the Transesterification of Soybean Oil to Biodiesel with Methanol. Fuel. 87:1076-1082.

Long, Y. D., Guo, F., Fang, Z., Tian, X. F., Jiang, L. Q., and Zhang, F. 2011. Production of Biodiesel and Lactic Acid from Rapeseed Oil Using Sodium Silicate as Catalyst. Bioresource Technology. 102:6884-6886.

Marjanovic, A. V., Stamenkovic, O. S., Todorovic, Z. B., Lazic, M. L., and Veljkovic, V. B. 2010. Kinetics of The Base-Catalyzed Sunflower Oil Ethanolysis. Fuel. 89:665-671.

Reningtyas, R., Perdana, I., and Bendiyasa, I.M. 2012. Purification of Silica Recovered from Dieng's Geothermal Sludge. Seminar Proceeding of the $19^{\text {th }}$ Regional Seminar on Chemical Engineering (RSCE) 2012, Denpasar, November 2012.

Richard, R., Li, Y., Dubreuil, B., Thiebaud-Roux, S., and Prat, L. 2011. On-line Monitoring of the Transesterification Reaction between Triglycerides and Ethanol using Near Infrared Sectroscopy Combined with Gas Chromatography. Bioresource Technology. 102:6702-6709.

Riyanto, N., Sumardi, P. C., and Perdana, I. 2010. Recovery of MicroAmorphous Silica from Dieng's Geothermal Sludge via Sol-Gel Extraction. Seminar proceeding of Regional Seminar on Chemical Engineering (RSCE) 2010, Bangkok, Thailand, November 2010.

Wang, B., Li, S., Tian, S., Feng, R., and Meng., Y. 2013. A New Solid Base Catalyst for the Transesterification of Rapeseed Oil to Biodiesel with Methanol. Fuel. 104:698-703. 